\title{
Research Article \\ Effect of Inflammatory Mediators on ATP Release of Human Urothelial RT4 Cells
}

\author{
Kylie J. Mansfield and Jessica R. Hughes \\ Graduate School of Medicine, Illawarra Health and Medical Research Institute, University of Wollongong, Wollongong, \\ NSW 2522, Australia \\ Correspondence should be addressed to Kylie J. Mansfield; kylie@uow.edu.au
}

Received 28 February 2014; Accepted 2 April 2014; Published 15 April 2014

Academic Editor: Gilho Lee

Copyright (C) 2014 K. J. Mansfield and J. R. Hughes. This is an open access article distributed under the Creative Commons Attribution License, which permits unrestricted use, distribution, and reproduction in any medium, provided the original work is properly cited.

\begin{abstract}
Inflammation is an important contributor to the aetiology of a number of bladder dysfunctions including interstitial cystitis, painful bladder syndrome, and overactive bladder. The aim of this study was to examine the effects of inflammatory mediators on urothelial ATP release. Human urothelial RT4 cells were exposed to normal buffer or varying concentrations of inflammatory mediators (bradykinin, histamine, and serotonin) in the presence or absence of hypotonic stretch stimuli (1:2 dilution of Krebs-Henseleit buffer). Others have demonstrated that bradykinin increased stretch-induced ATP release; however, we observed no change in control or stretch-induced ATP release with bradykinin. Pretreatment of RT4 cells with histamine or serotonin decreased stretchinduced ATP release $(P=0.037, P=0.040$, resp.). Previous studies have demonstrated increased ATP release in response to inflammation utilising whole bladder preparations in contrast to our simple model of cultured urothelial cells. The current study suggests that it is unlikely that there is a direct interaction between the release of inflammatory mediators and increased ATP release, but rather more complex interactions occurring in response to inflammation that lead to increased bladder sensation.
\end{abstract}

\section{Introduction}

Inflammation is an important contributor to the aetiology of a number of bladder dysfunctions. Pyuria (the presence of white blood cells in the urine) has been associated with lower urinary tract symptoms [1] and biopsy specimens from patients with interstitial cystitis (IC)/painful bladder syndrome (PBS) are commonly characterised by the presence of inflammatory cells in the lamina propria, especially infiltration with mast cells [2-7]. Recently, histological evidence for chronic inflammatory infiltrate has been demonstrated in patients with refractory overactive bladder (OAB) [8] together with pyuria in these patients $[8,9]$. Proinflammatory cytokines are increased in the urine from patients with $\mathrm{OAB}$ [10-12].

These conditions (IC/PBS/OAB) are all characterised by urinary urgency, together with frequency and nocturia [13]. It is believed that bladder sensation is associated with the interaction of ATP with purinergic receptors located on suburothelial afferent nerves [14, 15] and myofibroblasts [15].
ATP is released from the urothelium in response to stretch of the urothelium triggered by bladder filling [16]. An increase in stretch-induced ATP release has been demonstrated in tissue strips and biopsies from patients with IC/PBS [1719] and OAB [20]. In addition, the concentration of ATP in intravesical fluid has been shown to correlate with urinary urgency as indicated by the volume at first desire to void in patients with $\mathrm{OAB}[21,22]$.

Similar to the changes in bladder histological structure described with PBS/IC, chemical-induced cystitis causes histological changes in the bladder wall including infiltration of inflammatory cells (e.g., mast cells and macrophages) into the submucosa [4-7], together with increased bladder weight and oedema. In addition, chemical cystitis is associated with activation of previously silent C-fibre afferents and sensitisation of mechanosensitive $\mathrm{A} \delta$-fibres within the submucosa [23-26].

The effect of inflammation causing an increase in urothelial ATP release has been examined in animal models of inflammation, including feline interstitial cystitis [27], 
cyclophosphamide cystitis [28], and ketamine cystitis [2]. However, the agents responsible for the increased ATP release are unknown. The aim of this study was to examine the effects of bradykinin, histamine, and serotonin, mediators commonly associated with bladder inflammation, on urothelial cell ATP release.

\section{Materials and Methods}

2.1. Cell Culture. Human urothelial RT4 cells (obtained from the ECACC) were grown at $37^{\circ} \mathrm{C}$ with $5 \% \mathrm{CO}_{2}$ in McCoy's $5 \mathrm{~A}$ culture medium supplemented with $10 \%$ foetal bovine serum, 100 units $/ \mathrm{mL}$ of penicillin, $100 \mu \mathrm{g} / \mathrm{mL}$ of streptomycin, and $0.25 \mu \mathrm{g} / \mathrm{mL}$ of fungizone. At confluence, cells were passaged and then replated onto T75 flasks for continuous passage or onto 24 well plates for use in ATP release when confluent (approximately 3 to 5 days after passage).

2.2. ATP Release. ATP release was determined as previously described [29]. Urothelial cells were washed (three times) with carbogenated Krebs-Henseleit solution (containing mM: $\mathrm{NaCl} 118, \mathrm{KCl} 4.7, \mathrm{NaHCO}_{3} 25, \mathrm{KH}_{2} \mathrm{PO}_{4} 1.2, \mathrm{MgSO}_{4}$ 1.2, $\mathrm{CaCl}_{2} 2.5$, and D-glucose 11.7). The basal level of ATP release was then determined by 10 -minute incubation in $500 \mu \mathrm{L}$ Krebs-Henseleit solution. Cells were then exposed to normal Krebs-Henseleit (control) or the indicated concentration of mediator (bradykinin, histamine, and serotonin) in the presence or absence of hypotonic Krebs-Henseleit (1:2 dilution of Krebs-Henseleit in distilled water). Hypotonic Krebs-Henseleit was used as a stretch stimulus to examine the effect of the mediators on stretch-induced ATP release. Cells were treated for $10 \mathrm{~min}$ before the supernatant $(200 \mu \mathrm{L})$ was collected and used for ATP determinations.

ATP concentration in the supernatant was measured using the bioluminescence assay. Equal volumes of the cellular supernatant or ATP standard solutions $\left(10^{-6}\right.$ to $\left.10^{-10} \mathrm{M}\right)$ were mixed with the bioluminescence assay mix and the luminescence generated was measured immediately using a plate reader (BMG Labtech Polarstar). The ATP concentration in the cell supernatant was calculated relative to the standard curve. Treatments were carried out in triplicate and the mean ATP concentration (in $\mathrm{nM}$ ) per treatment was determined.

2.3. Statistics. As results are nonnormally distributed and as such are expressed as median with interquartile range (IQR); two different treatments were compared using a Wilcoxon matched-pairs $t$-test. Dose response relationships were examined using a sigmoidal dose response curve. All statistics were performed using Graphpad Prims (version 6) (San Diego, CA).

2.4. Materials. All cell culture reagents were purchased from Invitrogen (Mount Waverley, Australia). Bioluminescence ATP assay kit and mediators (bradykinin, histamine, and serotonin) were from Sigma-Aldrich (Sydney, Australia). All other reagents were of high analytical grade.

\section{Results and Discussion}

3.1. Effect of Bradykinin on Urothelial Cell ATP Release. Bradykinin is a peptide neurotransmitter released from sensory afferent nerves. Bradykinin release is closely associated with inflammatory responses. Distension of the bladder has been shown to stimulate release of bradykinin in patients with IC indicating a potential role for this peptide in the pathophysiology of this disorder [30]. Bradykinin exerts its physiological actions via activation of B1 and B2 receptors. Bradykinin B2 receptors are believed to be important in inflammatory pain with animal models showing that block of this receptor reduces inflammatory hyperalgesia [31, 32]. In contrast, bradykinin $\mathrm{B} 1$ receptors are expressed at low levels under normal circumstances with their expression upregulated following tissue damage or inflammation [33]. This includes upregulation of bradykinin B1 receptors following cystitis induced by intravesical injection of the detergent Triton X100 [34]. Expression of bradykinin B1 receptors is increased in biopsies obtained from patients with interstitial cystitis [35] and, in cyclophosphamide-induced cystitis, B1 receptor mediated bladder responses are significantly increased [36, 37]. In addition, cyclophosphamide cystitis induced a bladder hyperactivity that was dependent on bradykinin $\mathrm{B} 2$ receptor activation and was inhibited by the $\mathrm{P} 2$ receptor antagonist PPADS [38]. This indicates a role for both bradykinin and ATP in cyclophosphamide-induced cystitis [38].

Other studies have observed that activation of bradykinin B2 receptors by bradykinin increases stretch-induced ATP release in UROtsa urothelial cells [39] and in primary cultures of rat urothelial cells [38]. However, in the current study, using urothelial RT4 cells, we saw no change in either control or stretch-induced ATP release in the presence of bradykinin (Figure 1). Hypotonic Krebs which was used as a positive control was seen to induce an approximate threefold increase in ATP release (baseline ATP release 34.06 (23.8-99.1) Nm; stretch-induced ATP release 146.7 (72.4-217.6) $\mathrm{nM}, P=$ 0.002 ). It is possible that the differences in these findings relate to the individual cell lines used and that the bradykinin receptors usually present on urothelial cells are not functional on RT4 urothelial cells.

\subsection{Effect of Mast Cell Mediators on Urothelial Cell ATP} Release. Infiltration of inflammatory cells such as mast cells and macrophages into the bladder submucosa has been demonstrated in cyclophosphamide-induced cystitis [3] and ketamine-induced cystitis [2]. In addition, it is well known that there is an increased density of mast cells in the bladder wall in patients with IC [4-7]. Mast cells lie in close proximity to both urothelial cells and afferent fibres in the submucosa of the urinary bladder, and degranulation of these cells has been shown to release a wide range of neurotransmitters and cytokines [38].

Mast cells are granulated immune system cells which make up the major sensory arm of the innate immune system [40]. Mast cells respond to allergens as well as nonimmunologic stimuli such as bacteria, chemicals, kinins, and neuropeptides [41] to release mediators such as histamine and 


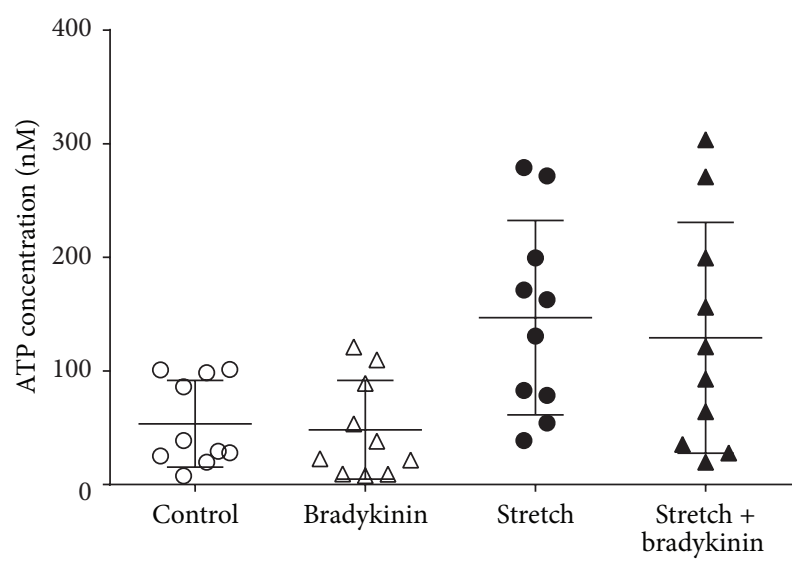

FIGURE 1: Effect of bradykinin $(1 \mu \mathrm{M}, n=10)$ on baseline level of ATP release and release induced by hypotonic media. Symbols are representative of individual data points for the four groups. Data are shown as median with interquartile range.

serotonin [42]. There are reports of increased concentrations of histamine in urine from IC patients [41] and it is believed that the pain associated with bladder filling in IC is related to release of histamine from mast cells in the bladder wall [43].

In this study, the effect of mast cell mediators, histamine and serotonin, on urothelial cell ATP release was examined. Incubation of the RT4 cells with mast cell mediators, histamine and serotonin, for 10 minutes had no effect on control ATP release (Figures 2(a) and 2(c)). However, pretreatment of urothelial cells with histamine or serotonin for a 10-minute period prior to the addition of the hypotonic stretch stimulus resulted in a decrease in ATP release in response to stretch (Figure 2(a), $P=0.037$ for histamine; Figure 2(c), $P=0.040$ for serotonin). When the concentration response effect of histamine on stretch-induced ATP release was determined, it was seen to occur with an IC50 of $0.24 \mu \mathrm{M}(0.19-2.8 \mu \mathrm{M})$ (Figure $2(b), n=6$ ). This concentration is within the histamine concentration range that has been reported in urine from IC patients ( 3 to $31 \mathrm{ng} / \mathrm{mL}$, equating to 24 to $280 \mathrm{nM}$ ) [43]. The slope of the concentration response curve was fairly shallow with a Hill slope of $-0.74 \pm 0.19$. A similar concentration dependent inhibition of ATP release was also elucidated for serotonin. In this instance, an IC50 of $1.7 \mathrm{nM}$ $(<0.001 \mathrm{nM}-50.0 \mu \mathrm{M})$ was determined with a Hill slope of $-0.37 \pm 0.24$ (Figure $2(\mathrm{~d}), n=6$ ).

While the effect of the mast cell mediators on urothelial cell ATP release has never previously been examined, the results obtained were somewhat unexpected. Previous studies have shown an increase in ATP release from the bladder in response to inflammation [17-19, 27, 28]. However, all of these studies were conducted in whole tissue models of inflammation. In these models, determining the causative molecule or cell is complex as numerous interactions between different cell types and mediators are occurring in the one system which could change receptor expression in addition to mediator release in response to the inflammatory stimulus. The model used in the current study of cultured urothelial cells is a much simpler model containing only a single cell type and a single exogenously supplied mediator. It is possible that in the previous studies it was not the inflammatory mediators themselves that were inducing the increase in ATP release, but rather secondary changes that occurred in response to the inflammation. Decreasing importance of ATP in inflamed bladder is supported by findings that the P2 antagonist (PPADS) decreased voiding frequency in control animals but not in cyclophosphamide treated animals [44].

Inflammation causes a number of changes in the bladder. For example, cyclophosphamide induced an increase in COX2 protein expression in the urothelium, which was dependent on release of mediators from mast cells [45]; in addition, cyclophosphamide also increases prostaglandin $\mathrm{E}_{2}$ production [46]. Prostaglandin $\mathrm{E}_{2}$ has been shown to increase urothelial cell ATP release [47]. It is also possible that in response to inflammation there are changes in receptor expression that would alter the response of urothelial cells to these mast cell mediators. As mentioned previously, bradykinin B1 receptors are expressed at very low levels under normal conditions but are upregulated following inflammation [38]. It is possible that a similar phenomenon occurs for histamine and serotonin receptors on the urothelium although this has not been examined to date.

In addition, there are further changes that occur in the inflamed bladder including defects in urothelial junction proteins, increased suburothelial inflammation, and increased urothelial cell apoptosis [2]. Bladder inflammation is associated with disruption of the glycosaminoglycan layer that covers the urothelium [48-50]. Disruption of this layer may allow urine contents to evoke irritation and inflammation within the bladder wall. There is also increased density of submucosal afferent nerves in the inflamed bladder $[43,51,52]$. Urinary nerve growth factor (NGF) levels are increased in patients with IC [53] and OAB [54]. In addition, cyclophosphamide-induced cystitis is associated with increased NGF mRNA levels in the bladder [55], increases the density of afferent nerves, and increases expression of $\mathrm{P} 2 \mathrm{X}_{2}$ and $\mathrm{P} 2 \mathrm{X}_{2 / 3}$ receptors in afferent nerves [56]. It is likely that the increase in NGF expression in patients with bladder dysfunction is associated with the increased density of suburothelial nerves in these patients. NGF is also thought to alter expression of neurotransmitters, modulate ion channels, and increase excitability of afferent nerves [57]. In rats, exogenously applied intravesical NGF can induce bladder nociceptive responses and bladder overactivity [58]. In addition to NGF, inflammatory mediators themselves may sensitise the afferent nerves to the effects of ATP $[56,59]$, which could increase the bladder sensations in response to bladder filling in the inflamed bladder.

\section{Conclusions}

It is well accepted that bladder inflammation is associated with increased signalling from the bladder and increased sensation. Studies using whole bladder models of inflammation have shown that this is due to increased release of ATP from the urothelium. However, based on the results of the current study, it appears unlikely that there is a simple 


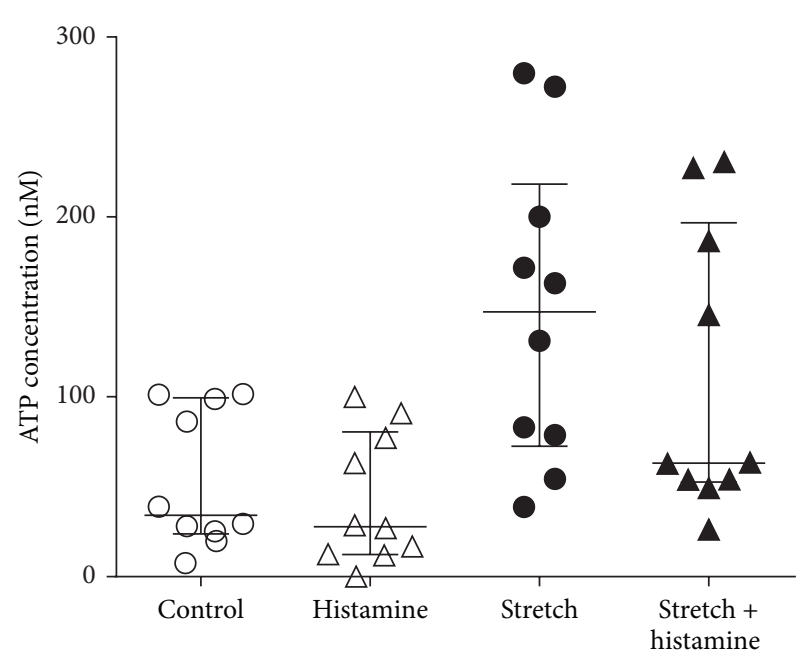

(a)

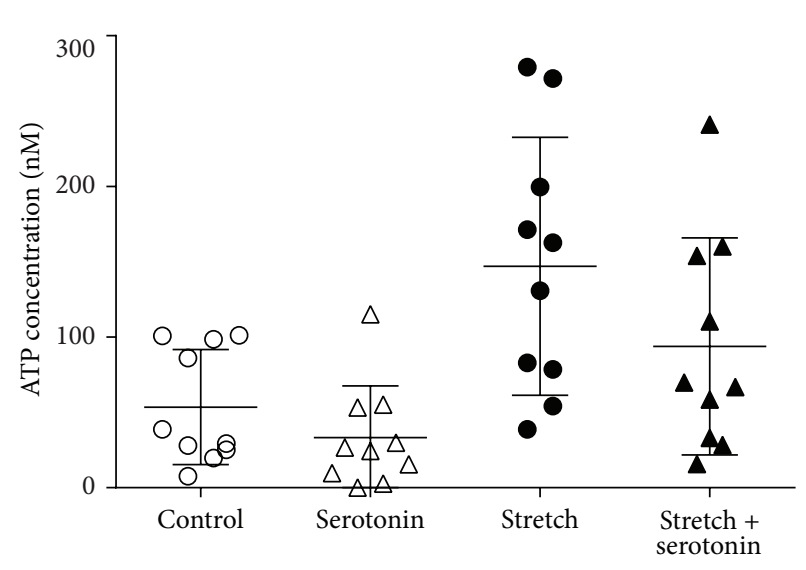

(c)

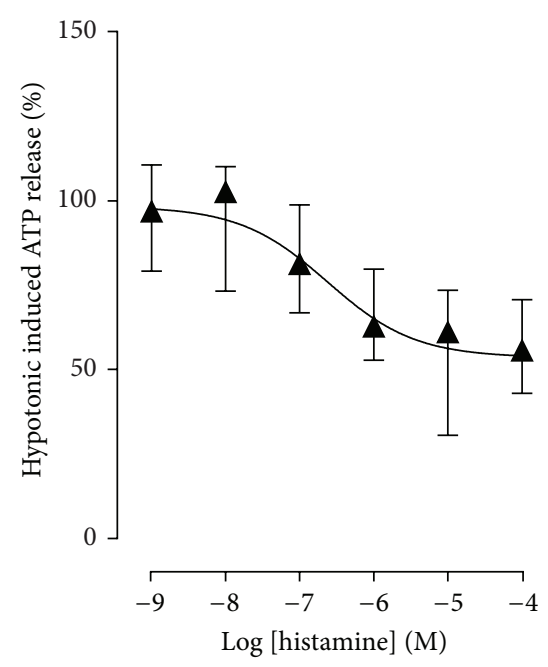

(b)

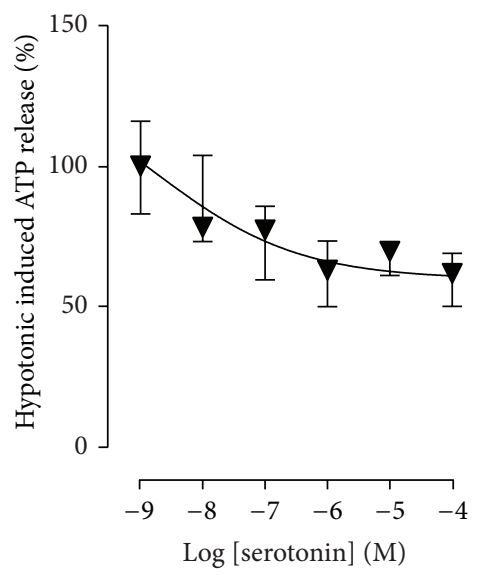

(d)

Figure 2: Effect of histamine $(1 \mu \mathrm{M})((\mathrm{a}), n=10)$ and serotonin $(1 \mu \mathrm{M})((\mathrm{c}), n=10)$ on baseline level of ATP release and release induced by hypotonic media. Data are shown as median with interquartile range. Concentration response relationships for the inhibition of ATP release induced by hypotonic media in the presence of histamine ((b), $n=10)$ and serotonin $((\mathrm{d}), n=10)$.

interaction between the release of the inflammatory mediators (bradykinin, histamine, and serotonin) and increased ATP release leading to increased bladder sensation. It is more likely that there are numerous factors involved in the interaction between bladder inflammation and increased sensation. These factors include alterations to receptor expression on the urothelium and afferent nerves, increased density of afferent nerves, and hyperresponsiveness of the afferent nerves, altering the neuronal component of afferent signalling.

\section{Conflict of Interests}

The authors declare that there is no conflict of interests regarding the publication of this paper.

\section{Acknowledgments}

The authors thank Dr. Catherine McDermott and Professor Russ Chess-Williams from Bond University for their assistance with cell culture studies. This study was supported by a Small URC grant from the University of Wollongong and by funding from the Illawarra Health and Medical Research Institute. The authors would also like to thank Tim Cowan for assistance with assaying ATP bioluminescence.

\section{References}

[1] K. N. Moore, S. Murray, J. Malone-Lee, and A. Wagg, "Rapid urinalysis assays for the diagnosis of urinary tract infection," British Journal of Nursing, vol. 10, no. 15, pp. 995-1001, 2001.

[2] C. L. Lee, Y. H. Jiang, and H. C. Kuo, "Increased apoptosis and suburothelial inflammation in patients with ketamine-related cystitis: a comparison with non-ulcerative interstitial cystitis and controls," BJU International, vol. 112, no. 8, pp. 1156-1162, 2013.

[3] P. Aronsson, M. Johnsson, R. Vesela, M. Winder, and G. Tobin, "Adenosine receptor antagonism suppresses functional and histological inflammatory changes in the rat urinary bladder," Autonomic Neuroscience: Basic and Clinical, vol. 171, no. 1, pp. 49-57, 2012. 
[4] F. Aldenborg, M. Fall, and L. Enerback, "Proliferation and transepithelial migration of mucosal mast cells in interstitial cystitis," Immunology, vol. 58, no. 3, pp. 411-416, 1986.

[5] P. M. Hanno, D. R. Staskin, and R. J. Krane, Interstitial Cystitis, Springer, New York, NY, USA, 1990.

[6] L. Enerback, M. Fall, and F. Aldenborg, "Histamine and mucosal mast cells in interstitial cystitis," Agents and Actions, vol. 27, no. 1-2, pp. 113-116, 1989.

[7] T. C. Theoharides, D. Kempuraj, and G. R. Sant, "Mast cell involvement in interstitial cystitis: a review of human and experimental evidence," Urology, vol. 57, no. 6, supplement 1, pp. 47-55, 2001.

[8] K. Moore, D. Richmond, and J. Sutherst, "Urinary acidity in relation to detrusor instability," Neurourology and Urodynamics, vol. 9, pp. 331-332, 1990.

[9] K. Kjærgaard, M. A. Schembri, C. Ramos, S. Molin, and P. Klemm, "Antigen 43 facilitates formation of multispecies biofilms," Environmental Microbiology, vol. 2, no. 6, pp. 695-702, 2000.

[10] Y. Cheng, N. J. C. King, and A. M. Kesson, "The role of tumor necrosis factor in modulating responses of murine embryo fibroblasts by flavivirus, West Nile," Virology, vol. 329, no. 2, pp. 361-370, 2004.

[11] K. H. Moore, D. M. Hay, A. E. Imrie, A. Watson, and M. Goldstein, "Oxybutynin hydrochloride $(3 \mathrm{mg})$ in the treatment of women with idiopathic detrusor instability," British Journal of Urology, vol. 66, no. 5, pp. 479-485, 1990.

[12] C. Walsh, A. Siddins, K. Parkin, C. Mukerjee, and K. H. Moore, "Prevalence of "low-count" bacteriuria in female urinary incontinence versus continent female controls: a crosssectional study," International Urogynecology Journal, vol. 22, no. 10, pp. 1267-1272, 2011.

[13] P. Abrams, L. Cardozo, M. Fall et al., "The standardisation of terminology of lower urinary tract function: report from the standardisation sub-committee of the International Continence Society," Neurourology and Urodynamics, vol. 21, no. 2, pp. 167178, 2002.

[14] D. A. Cockayne, S. G. Hamilton, Q.-M. Zhu et al., "Urinary bladder hyporeflexia and reduced pain-related behaviour in P2X ${ }_{3}$-deficient mice," Nature, vol. 407, no. 6807, pp. 1011-1015, 2000 .

[15] M. Vlaskovska, L. Kasakov, W. Rong et al., "P2X 3 knock-out mice reveal a major sensory role for urothelially released ATP," The Journal of Neuroscience, vol. 21, no. 15, pp. 5670-5677, 2001.

[16] D. R. Ferguson, I. Kennedy, and T. J. Burton, "ATP is released from rabbit urinary bladder epithelial cells by hydrostatic pressure changes-a possible sensory mechanism?" The Journal of Physiology, vol. 505, part 2, pp. 503-511, 1997.

[17] V. Kumar, C. R. Chapple, A. M. Surprenant, and R. ChessWilliams, "Enhanced adenosine triphosphate release from the urothelium of patients with painful bladder syndrome: a possible pathophysiological explanation," The Journal of Urology, vol. 178, no. 4, pp. 1533-1536, 2007.

[18] Y. Sun and T. C. Chai, "Augmented extracellular ATP signaling in bladder urothelial cells from patients with interstitial cystitis," American Journal of Physiology: Cell Physiology, vol. 290, no. 1, pp. C27-C34, 2006.

[19] Y. A. N. Sun, S. Keay, P. G. de Deyne, and T. C. Chai, "Augmented stretch activated adenosine triphosphate release from bladder uroepithelial cells in patients with interstitial cystitis," The Journal of Urology, vol. 166, no. 5, pp. 1951-1956, 2001.
[20] V. Kumar, C. R. Chapple, D. Rosario, P. R. Tophill, and R. ChessWilliams, "In vitro release of adenosine triphosphate from the urothelium of human bladders with detrusor overactivity, both neurogenic and idiopathic," European Urology, vol. 57, no. 6, pp. 1087-1092, 2010.

[21] Y. Cheng, K. J. Mansfield, W. Allen, C. A. Walsh, E. Burcher, and K. H. Moore, "Does adenosine triphosphate released into voided urodynamic fluid contribute to urgency signaling in women with bladder dysfunction?" The Journal of Urology, vol. 183, no. 3, pp. 1082-1086, 2010.

[22] Y. Cheng, K. J. Mansfield, W. Allen, R. J. Millard, E. Burcher, and K. H. Moore, "Correlation between cystometric volumes, ATP release, and $\mathrm{pH}$ in women with overactive bladder versus controls," Neurourology and Urodynamics, vol. 32, no. 7, pp. 969973, 2013.

[23] C. A. Maggi, "Prostanoids as local modulators of reflex micturition," Pharmacological Research, vol. 25, no. 1, pp. 13-20, 1992.

[24] A. Ahluwalia, C. A. Maggi, P. Santicioli, A. Lecci, and S. Giuliani, "Characterization of the capsaicin-sensitive component of cyclophosphamide-induced inflammation in the rat urinary bladder," British Journal of Pharmacology, vol. 111, no. 4, pp. 1017-1022, 1994.

[25] A. Lecci, S. Giuliani, P. Santicioli, and C. A. Maggi, "Involvement of spinal tachykinin $\mathrm{NK}_{1}$ and $\mathrm{NK}_{2}$ receptors in detrusor hyperreflexia during chemical cystitis in anaesthetized rats," European Journal of Pharmacology, vol. 259, no. 2, pp. 129-135, 1994.

[26] M. A. Vizzard, S. L. Erdman, and W. C. de Groat, "Increased expression of neuronal nitric oxide synthase in bladder afferent pathways following chronic bladder irritation," The Journal of Comparative Neurology, vol. 370, no. 2, pp. 191-202, 1996.

[27] L. A. Birder, S. R. Barrick, J. R. Roppolo et al., "Feline interstitial cystitis results in mechanical hypersensitivity and altered ATP release from bladder urothelium," American Journal of Physiology: Renal Physiology, vol. 285, no. 3, pp. F423-F429, 2003.

[28] C. P. Smith, V. M. Vemulakonda, S. Kiss, T. B. Boone, and G. T. Somogyi, "Enhanced ATP release from rat bladder urothelium during chronic bladder inflammation: effect of botulinum toxin A," Neurochemistry International, vol. 47, no. 4, pp. 291-297, 2005.

[29] Y. Cheng, K. J. Mansfiled, S. L. Sandow, P. Sadananda, E. Burcher, and K. H. Moore, "Porcine bladder urothelial, myofibroblast and detrusor muscle cells: characterisation and ATP release," Frontiers in Pharmacology, vol. 2, article 27, 2011.

[30] A. Rosamilia, J. A. Clements, P. L. Dwyer, M. Kende, D. J. Campbell, and P. M. Hanno, "Activation of the kallikrein kinin system in interstitial cystitis," The Journal of Urology, vol. 162, no. 1, pp. 129-134, 1999.

[31] K. Wirth, F. J. Hock, U. Albus et al., "Hoe 140 a new potent and long acting bradykinin-antagonist: in vivo studies," British Journal of Pharmacology, vol. 102, no. 3, pp. 774-777, 1991.

[32] M. Asano, N. Inamura, C. Hatori et al., "The identification of an orally active, nonpeptide bradykinin $\mathrm{B}_{2}$ receptor antagonist, FR173657," British Journal of Pharmacology, vol. 120, no. 4, pp. 617-624, 1997.

[33] A. Ahluwalia and M. Perretti, " $B_{1}$ receptors as a new inflammatory target. Could this B the 1?" Trends in Pharmacological Sciences, vol. 20, no. 3, pp. 100-104, 1999.

[34] F. Marceau, J. Barabe, S. St-Pierre, and D. Regoli, "Kinin receptors in experimental inflammation," Canadian Journal of Physiology and Pharmacology, vol. 58, no. 5, pp. 536-542, 1980. 
[35] M. R. Ruggieri, J. Wang, and K. E. Whitmore, "Expression of bradykinin 1 receptor subtype in interstitial cystitis bladder biopsies," The Journal of Urology, vol. 157, pp. 131-136, 1997.

[36] S. Meini, A. Lecci, P. Cucchi, R.-M. Catalioto, M. Criscuoli, and C. A. Maggi, "Inflammation modifies the role of cyclooxygenases in the contractile responses of the rat detrusor smooth muscle to kinin agonists," The Journal of Pharmacology and Experimental Therapeutics, vol. 287, no. 1, pp. 137-143, 1998.

[37] A. Lecci, S. Meini, M. Tramontana, S. Giuliani, M. Criscuoli, and C. A. Maggi, "Kinin $B_{1}$ receptor-mediated motor responses in normal or inflamed rat urinary bladder in vivo," Regulatory Peptides, vol. 80, no. 1-2, pp. 41-47, 1999.

[38] B. Chopra, S. R. Barrick, S. Meyers et al., "Expression and function of bradykinin $\mathrm{B}_{1}$ and $\mathrm{B}_{2}$ receptors in normal and inflamed rat urinary bladder urothelium," The Journal of Physiology, vol. 562, no. 3, pp. 859-871, 2005.

[39] P. Ochodnický, M. B. Michel, J. J. Butter, J. N. Panicker, and M. C. Michel, "Bradykinin modulates spontaneous nerve growth factor production and stretch-induced ATP release in human urothelium," Pharmacological Research, vol. 70, no. 1, pp. 147154, 2013.

[40] A. L. S. John and S. N. Abraham, "Innate immunity and its regulation by mast cells," The Journal of Immunology, vol. 190, no. 9, pp. 4458-4463, 2013.

[41] G. R. Sant, D. Kempuraj, J. E. Marchand, and T. C. Theoharides, "The mast cell in interstitial cystitis: role in pathophysiology and pathogenesis," Urology, vol. 69, no. 4, supplement, pp. S34-S40, 2007.

[42] T. Sakai, K.-I. Kasahara, K.-I. Tomita, I. Ikegaki, and H. Kuriyama, "5-Hydroxytryptamine-induced bladder hyperactivity via the $5-\mathrm{HT}_{2 \mathrm{~A}}$ receptor in partial bladder outlet obstruction in rats," American Journal of Physiology: Renal Physiology, vol. 304, no. 7, pp. F1020-F1027, 2013.

[43] T. Lundeberg, H. Liedberg, L. Nordling, E. Theodorsson, A. Owzarski, and P. Ekman, "Interstitial cystitis: correlation with nerve fibres, mast cells and histamine," British Journal of Urology, vol. 71, no. 4, pp. 427-429, 1993.

[44] M. Andersson, P. Aronsson, D. Giglio, A. Wilhelmson, P. Jeřábek, and G. Tobin, "Pharmacological modulation of the micturition pattern in normal and cyclophosphamide pretreated conscious rats," Autonomic Neuroscience: Basic and Clinical, vol. 159, no. 1-2, pp. 77-83, 2011.

[45] Z.-Y. Wang, P. Wang, and D. E. Bjorling, "Role of mast cells and protease-activated receptor-2 in cyclooxygenase-2 expression in urothelial cells," American Journal of Physiology: Regulatory Integrative and Comparative Physiology, vol. 297, no. 4, pp. R1127-R1135, 2009.

[46] V. Y. Hu, S. Malley, A. Dattilio, J. B. Folsom, P. Zvara, and M. A. Vizzard, "COX-2 and prostanoid expression in micturition pathways after cyclophosphamide-induced cystitis in the rat," American Journal of Physiology: Regulatory Integrative and Comparative Physiology, vol. 284, no. 2, pp. R574-R585, 2003.

[47] K. Matsumoto-Miyai, A. Kagase, Y. Murakawa, Y. Momota, and M. Kawatani, "Extracellular $\mathrm{Ca}^{2+}$ regulates the stimulus-elicited ATP release from urothelium," Autonomic Neuroscience: Basic and Clinical, vol. 150, no. 1-2, pp. 94-99, 2009.

[48] C. L. Parsons, "The therapeutic role of sulfated polysaccharides in the urinary bladder," Urologic Clinics of North America, vol. 21, no. 1, pp. 93-100, 1994.

[49] J. P. Lavelle, S. A. Meyers, W. G. Ruiz, C. A. T. Buffington, M. L. Zeidel, and G. Apodaca, "Urothelial pathophysiological changes in feline interstitial cystitis: a human model," American Journal of Physiology: Renal Physiology, vol. 278, no. 4, pp. F540-F553, 2000.

[50] G. Apodaca, S. Kiss, W. Ruiz, S. Meyers, M. Zeidel, and L. Birder, "Disruption of bladder epithelium barrier function after spinal cord injury," American Journal of Physiology: Renal Physiology, vol. 284, no. 5, pp. F966-F976, 2003.

[51] J. R. Hand, "Interstitial cystitis: report of 223 cases (204 women and 19 men)," The Journal of Urology, vol. 61, no. 2, pp. 291-310, 1994.

[52] T. J. Christmas, J. Rode, C. R. Chapple, E. J. G. Milroy, and R. T. Turner-Warwick, "Nerve fibre proliferation in interstitial cystitis," Virchows Archiv A: Pathological Anatomy and Histopathology, vol. 416, no. 5, pp. 447-451, 1990.

[53] H. T. Liu and H. C. Kuo, "Increased urine and serum nerve growth factor levels in interstitial cystitis suggest chronic inflammation is involved in the pathogenesis of disease," PLoS ONE, vol. 7, no. 9, article e44687, 2012.

[54] H.-T. Liu, C.-Y. Chen, and H.-C. Kuo, "Urinary nerve growth factor in women with overactive bladder syndrome," $B J U$ International, vol. 107, no. 5, pp. 799-803, 2011.

[55] M. A. Vizzard, "Changes in urinary bladder neurotrophic factor mRNA and NGF protein following urinary bladder dysfunction," Experimental Neurology, vol. 161, no. 1, pp. 273284, 2000.

[56] D. M. Daly, R. Chess-Williams, C. Chapple, and D. Grundy, "The inhibitory role of acetylcholine and muscarinic receptors in bladder afferent activity," European Urology, vol. 58, no. 1, pp. 22-28, 2010.

[57] W. C. de Groat, "Highlights in basic autonomic neuroscience: contribution of the urothelium to sensory mechanisms in the urinary bladder," Autonomic Neuroscience, vol.177, no. 2, pp. 6771, 2013.

[58] Y.-C. Chuang, M. O. Fraser, Y. Yu, M. B. Chancellor, W. C. de Groat, and N. Yoshimura, "The role of bladder afferent pathways in bladder hyperactivity induced by the intravesical administration of nerve growth factor," The Journal of Urology, vol. 165, no. 3, pp. 975-979, 2001.

[59] L. Bueno and J. Fioramonti, "Effects of inflammatory mediators on gut sensitivity," Canadian Journal of Gastroenterology, vol.13, supplement A, pp. 42A-46A, 1999. 


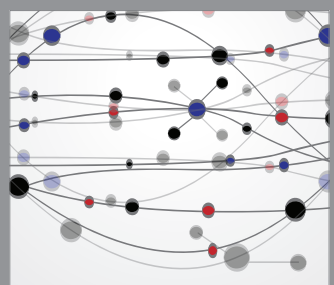

The Scientific World Journal
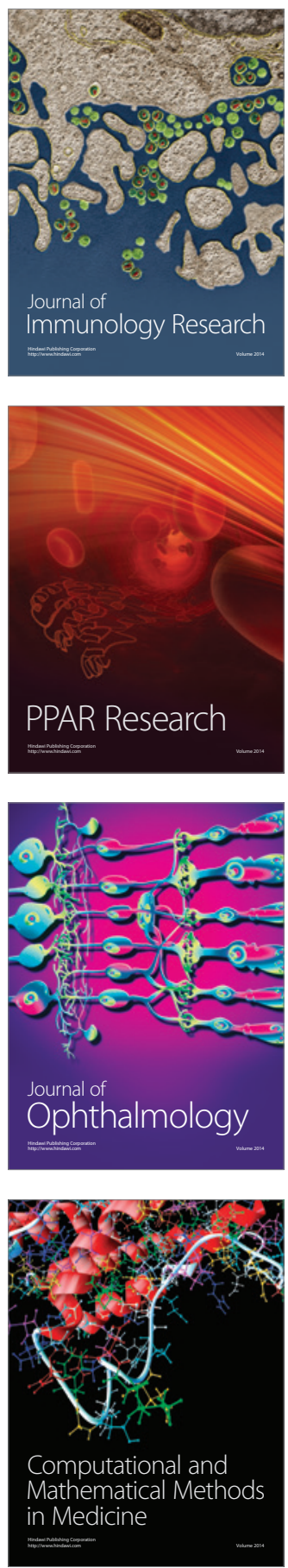

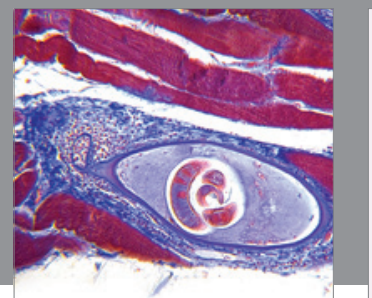

Gastroenterology

Research and Practice
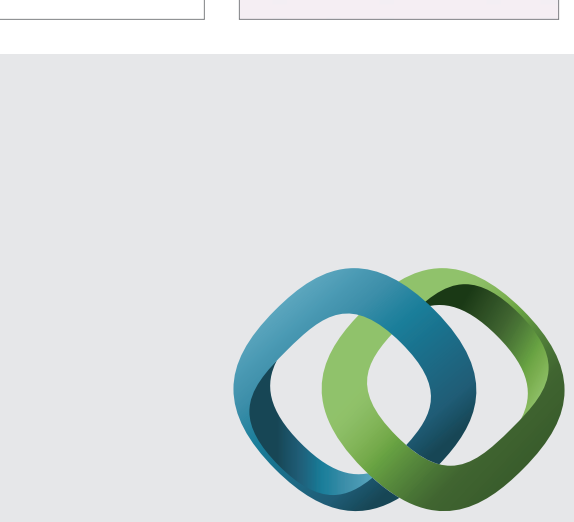

\section{Hindawi}

Submit your manuscripts at

http://www.hindawi.com
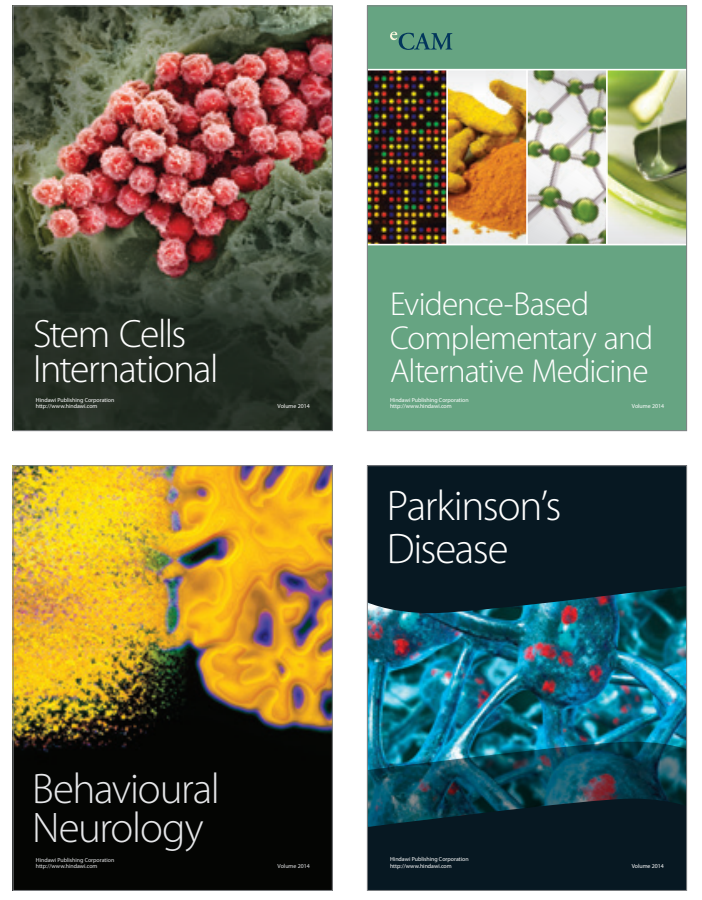
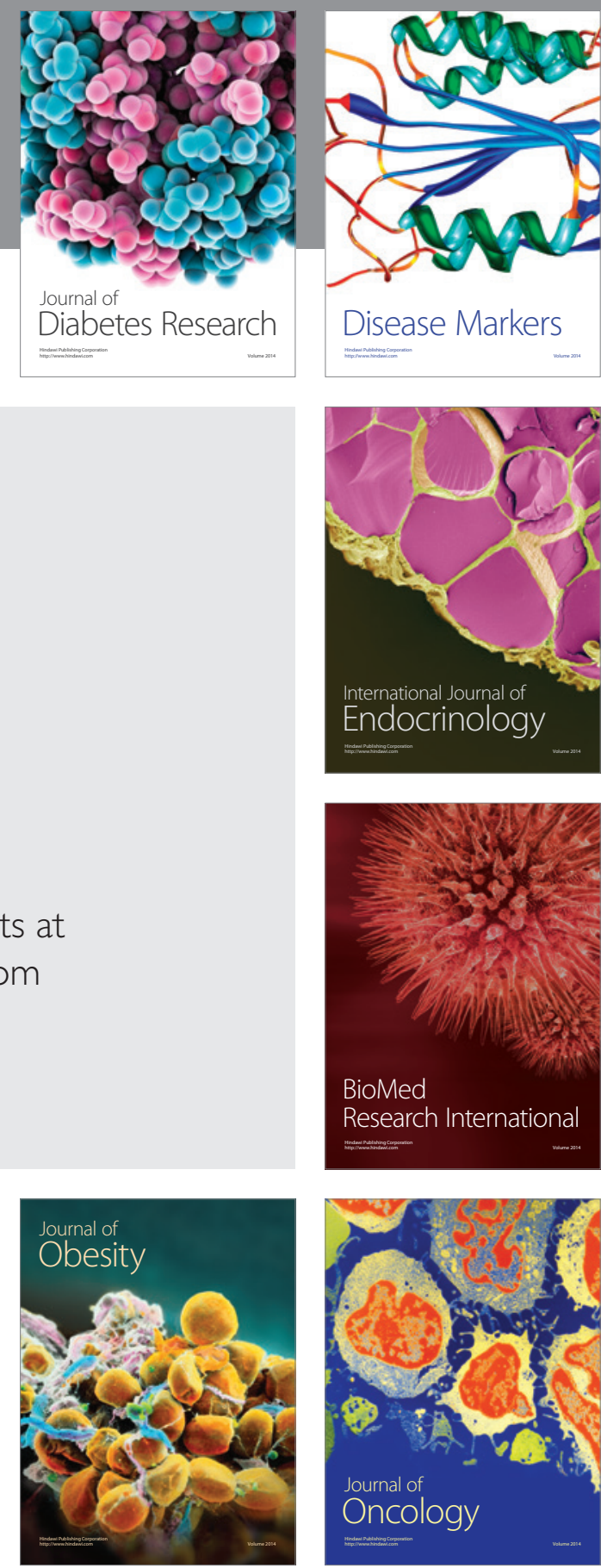

Disease Markers
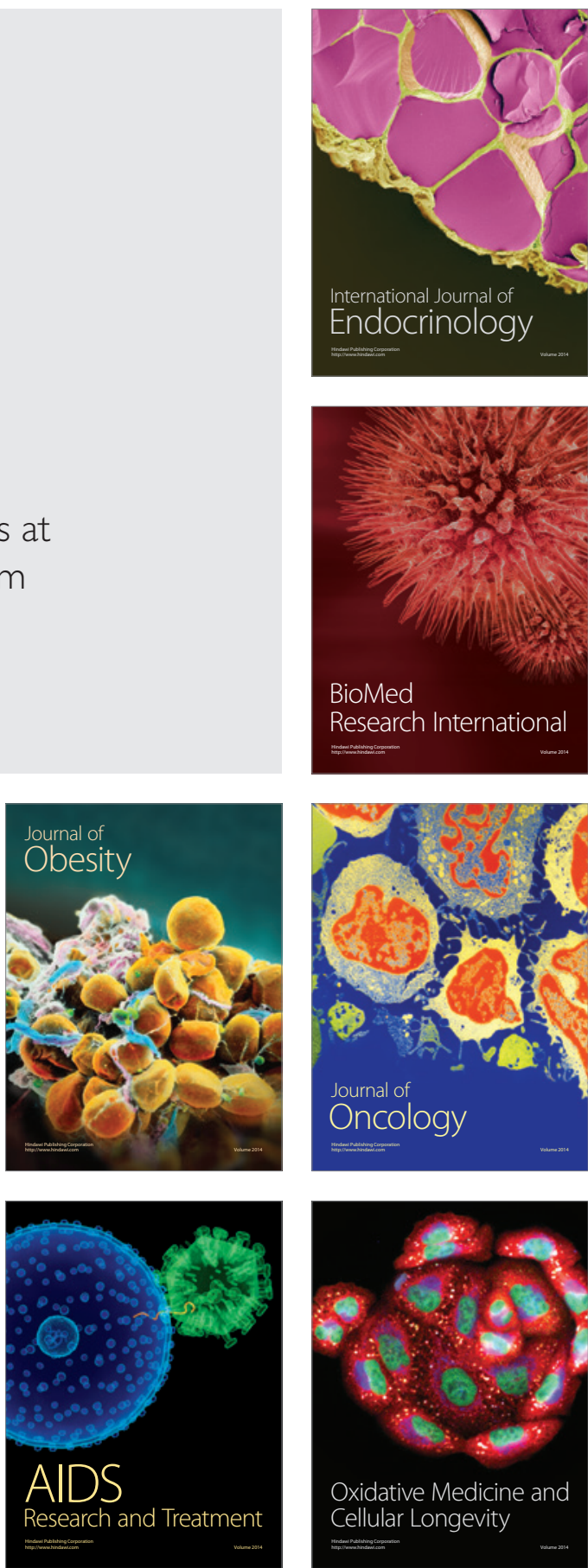